Article

\title{
Stakes and Challenges for Underwater Cultural Heritage in the Era of Blue Growth and the Role of Spatial Planning: Implications and Prospects in Greece
}

\author{
Marilena Papageorgiou (1) \\ Department of Planning and Development, Aristotle University of Thessaloniki, 54124 Thessaloniki, Greece; \\ marpapageo@plandevel.auth.gr
}

Received: 30 January 2019; Accepted: 26 March 2019; Published: 2 April 2019

\begin{abstract}
Underwater cultural heritage ( $\mathrm{UCH})$ constitutes an invaluable asset, which is lately being challenged by the blue growth trend that cannot be easily reconciled with the goal of $\mathrm{UCH}$ preservation and promotion. Maritime spatial planning (MSP)—under a place-based approach - creates better chances for $\mathrm{UCH}$ to receive more attention in the future compared to other resources, since it is considered to be the key procedure for tackling growing competition among sea users (user-user conflicts) and for mitigating the pressure these users put on the marine environment (natural and cultural). In Greece, a country with great insularity, extensive marine space, and a long and glorious past, $\mathrm{UCH}$ resources are in abundance. According to the official Ministry of Culture data-base, there are 88 designated UCH sites throughout the national waters, the majority of which are found very close to the shore. They usually concern ancient cities and built monuments that were eventually submerged (due to earthquakes, geological processes, etc.), so they usually have a mixed nature-terrestrial and marine. These sites, however, constitute a very small part of what is actually lying on the Greek seabed. Estimations for the future identify a rise in accidental discoveries of $\mathrm{UCH}$, due to the blue growth trend and an increase in access to and work in the sea. In this event, much controversy is expected, concerning the appropriate type of management for $\mathrm{UCH}$. The role of MSP in this decision-making process will be decisive, being about "when" and "where" human activities take place at sea, to ensure these are as efficient and sustainable as possible.
\end{abstract}

Keywords: Underwater cultural heritage (UCH); maritime spatial planning (MSP); blue growth; place-based approach; Greece

\section{Introduction}

According to estimations made by UNESCO, there are millions of wrecks worldwide spanning thousands of years of history, with hundreds of ancient cities now lying beneath water surfaces due to natural phenomena (changing sea levels, earthquakes, etc.) as well as manmade disasters (shifting landmasses, building of dams, etc.), and many geological formations (caves, etc.) that at some point were flooded, hiding prehistoric sites beneath the water surface [1,2]. Such valuable resources, however, are lately being challenged by the blue growth trend and the ever-growing interest in the development of maritime economic activities and infrastructure that may be directed at or indirectly affect underwater cultural heritage (hereinafter, $\mathrm{UCH}$ ).

So far, existing literature for $\mathrm{UCH}$, which is quite extensive, mainly focuses on issues of maritime archaeology and preservation [1,3]; on jurisdictions and rights as included in the international or regional legal documents [4-7] pertaining to management and promotion [8-10]; or in its correlation with natural and technological hazards and threats [11-13]. On the other hand, literature correlating 
$\mathrm{UCH}$ with stakes and challenges related to the blue growth trend-which, according to the EU is about supporting sustainable growth in the marine and maritime sectors as a whole-is still very limited. This fact, however, comes as no surprise, if one considers that the EU Integrated Maritime Policy (IMP) was announced in 2007, whilst the EU Maritime Spatial Planning (hereinafter MSP) Directive was launched in 2014.

Given the above, the present paper focuses on UCH resources, especially submarine, which are within the MSP geographical scope. It also highlights the increasing interest in blue growth (and the way it may affect $\mathrm{UCH}$ ) and the role of MSP in protecting and promoting $\mathrm{UCH}$. Focusing on the case of Greece, the paper aims at contributing to the ongoing discussion regarding the wise management and planning of the marine space (MSP), always taking into consideration the $\mathrm{UCH}$ parameter, which is lately being severely challenged by the blue growth trend-a trend that cannot be easily reconciled with the goal of UCH preservation and promotion.

\section{About Underwater Cultural Heritage}

\subsection{Definitions and Terms}

According to the UCH Convention of UNESCO (adopted in 2001), "Underwater Cultural Heritage" is defined as: All traces of human existence having a cultural, historical, or archaeological character, which have been partially or totally under water, periodically or continuously, for at least 100 years, such as: (i) Sites, structures, buildings, artefacts, and human remains, together with their archaeological and natural context; (ii) vessels, aircraft, other vehicles, or any part thereof, their cargo or other contents, together with their archaeological and natural context; and (iii) objects of prehistoric character. The convention names a wide range of $\mathrm{UCH}$ assets, also introducing a double criterion: (a) Time (giving a 100-year limit) and (b) significance (distinguishing UCH assets as cultural, historical, or archaeological) [5]. The convention excludes from the definition of $\mathrm{UCH}$ all types of pipelines and cables, as well as other installations placed on the seabed.

According to the Draft European Convention on underwater cultural heritage (Council of Europe, 1985), UCH resources may be found entirely or in part in seas, lakes, rivers, canals, artificial reservoirs, or other bodies of water; in tidal or other periodically flooded areas; recovered from any such environment; or washed ashore. Therefore, by its nature and definition, "underwater cultural heritage" has a strict geographical scope (cultural assets found within water bodies) and a strong tangible character (it is solely associated with tangible assets and resources). Other terms used instead of UCH by international documents (e.g., the 1954 Hague Convention) and literature are "underwater cultural property" and "submerged objects", due to the emphasis put on the tangible character of UCH and the rights for salvage and rescue of their content $[7,14]$.

\subsection{Stakes and Challenges for UCH in the Era of the Blue Growth Trend and the Role of Spatial Planning}

Marine space is constantly gaining ground as "home" to a growing number of activities and human uses [15]. Due to improvements in technology, today it is easier than ever to exploit marine resources found at longer distances and greater depths, as well as to construct resilient infrastructure and facilities in seas for the development of several economic activities [16]. As a result, the spectrum of human uses taking place in the sea has grown to include, apart from traditional activities (such as navigation and maritime transport, fisheries, etc.), a series of new ones, such as: Extraction of hydrocarbons and aggregates; energy production; aquaculture; tourism and leisure; research and protection of the marine natural and cultural heritage; military uses; and so on [17].

As recent research indicates, however $[18,19]$, this great-and usually unplanned-development of human uses and infrastructure in the sea (as a result of the blue growth trend) is not only threatening marine natural resources with exhaustion and degradation, but also UCH [17,18,20,21]. To address this challenge, marine/maritime spatial planning (MSP), which is "a public process of analyzing and allocating the spatial and temporal distribution of human activities in marine areas to achieve ecological, 
economic, and social objectives that usually have been specified through a political process" [22] has recently become a high priority globally. In fact, with increasing acknowledgment of the threats that the marine ecosystems are facing, more and more international organizations and bodies (or even sole countries) are turning their interest towards MSP, and especially towards MSP under a place-based approach.

This re-orientation of MSP from a sectorial-based approach (which emphasizes the growth of specific activities each time) to a place-based approach (which aims at organizing all human activities, so that user-user and user-environment conflicts are avoided) is of paramount importance to $\mathrm{UCH}$, which is now receiving growing pressure and threats due to the blue growth taking place in oceans and seas $[17,23]$.

MSP under a place-based approach creates better chances for $\mathrm{UCH}$ to receive more attention in terms of protection and management. At the same time, MSP under a place-based approach is considered to be suitable for tackling the growing competition among sea uses (user-user conflicts) and for mitigating the pressure these uses put on the marine environment (natural and cultural) $[24,25]$. However, even if place-based MSP occurs, the greatest challenge for UCH will be how to reconcile blue growth trends with UCH preservation and promotion: In other words, how should UCH be prioritized, compared to other marine economic activities and resources, when planning for human uses of the sea.

\section{Considering the UCH Parameter in MSP}

\subsection{Maritime Protection Zones and $\mathrm{UCH}$}

Protected areas (or protection zones) constitute a special type of zone, specifically addressing management and protection of natural and cultural heritage and assets. At an international level, zoning aimed at UCH protection-a special "cultural heritage protection zone" (The UCH convention on underwater cultural heritage was launched in 2001 to stipulate further provisions for the protection of UCH in areas beyond national jurisdiction. In the initial draft of the convention, a "cultural heritage protection zone" was proposed to assist a key objective of the convention, i.e., "in situ" protection [5]. This zone, however, was soon removed from later versions, for raising controversy with existing zoning provided by UNCLOS. If left, it could have been established by any coastal state party, covering areas beyond its territorial sea and up to the outer limit of the continental self, giving jurisdiction over all kinds of activities affecting UCH [2].) - was first conceptualized during the drafting of the United Nations UCH convention on underwater cultural heritage. Such a concept, though, never reached the final version of the convention. As a result, zoning explicitly addressing the protection of $\mathrm{UCH}$ is entirely a national affair. This means that conceptualization and designation of such zones (having as the sole focus protection of UCH resources) can only be undertaken individually by each state, either within its territory, territorial waters (According to UNCLOS (art.3), "Every State has the right to establish the breadth of its territorial sea up to a limit not exceeding 12 nautical miles, measured from baselines determined in accordance with this Convention"), or the contiguous zone (According to UNCLOS (art. 33), the contiguous zone may not extend beyond 24 nautical miles from the baselines from which the breadth of the territorial sea is measured.).

This complete absence of a special zone directly addressing UCH protection beyond the contiguous zone of a coastal state can be remediated by other zoning, having a more general and wider objective and focus, such as marine protected areas (MPAs). MPAs constitute spatially-delimited areas in the marine environment, within which certain human uses and activities are either permitted or not [26]. According to the International Union for the Conservation of Nature (IUCN), MPAs can be designated for a number of reasons, including: Economic resource management; biodiversity conservation; species protection; and the protective management of natural areas to keep them in good environmental and natural condition. $\mathrm{UCH}$, being an integral part of the marine natural ecosystem and landscape, may therefore benefit from the designation of such protection zones [27], especially in 
the cases where a cultural asset is located beyond the territorial waters or the contiguous zone of a coastal state (i.e., in areas where coastal states' jurisdictions over UCH do not apply).

The MPAs launched at an international and regional level (by the International Maritime Organization-IMO, UN, EU, etc.) include a range of specific intended purposes. These are described in the following paragraphs.

MARPOL special areas: The MARPOL Convention (International Convention for the Prevention of Pollution from Ships) was adopted in 1973 by the IMO. According to this convention, special areas can be recognized at an international level for technical reasons, or due to their particular character and oceanographical and ecological condition, for the purpose of adopting measures for the prevention of sea pollution by oil. The convention also provides for an "emission control area" designed to prevent, reduce, and control air pollution from NOx or SOx and the adverse impacts on human health and the environment.

Particularly Sensitive Sea Areas (PSSAs): Resolution A.982 (24) of IMO, provides the possibility for the designation of a PSSA, especially in areas fulfilling a set of ecological, social, cultural, and economic criteria (e.g., be a unique or rare ecosystem, be a significant area for education, recreation, or tourism, etc.). The designation of an area as a PSSA requires specific measures for the control of maritime activities in that area, including routing measures, etc. PSSAs can be included in MARPOL special areas and vice versa.

Special Protected Areas (SPAs) and Sites of Community Importance (SCIs): SPAs and SCIs, established by the European Union in 1992 (the Habitats Directive 1992/43), constitute the largest network of protected areas in the world. The network includes terrestrial and marine sites, providing protection to valuable and threatened species, and habitats of natural importance.

Specially Protected Areas of Mediterranean Interest (SPAMIs): The SPA/BD Protocol of the Barcelona Convention (UNEP/MAP) provided the possibility for the designation of SPAMIs. This type of protected area is established to promote cooperation in the management and conservation of natural areas, as well as to protect threatened species and their habitats found in the marine space of the Mediterranean. SPAMIs are also designated in marine areas of scientific, aesthetic, historical, archaeological, cultural, or educational interest.

Ecological Protection Zones (EPZ): Such zones are established in the EU and in the Mediterranean with the approval of the IMO. The primary objective is to preserve ecological biodiversity and, in some cases, living resources (such as fishes, etc.).

Given the above options and range of MPAs, selection of the most appropriate type of zone for the protection and management of UCH depends on: a) The distance from shore, i.e., if its location falls within the territorial waters (12 n.m. from the baseline) of a coastal state or within a proclaimed E.E.Z. (200 n.m. from the baseline); and b) the type of valuable resource found in the surrounding area of UCH. This is, of course, in the case that "in situ" protection and management of UCH is chosen.

\subsection{Sea-Use Planning in Areas Including UCH: Identifying Synergies and Conflicts}

Although the designation of natural and cultural protection zones is of prime importance for $\mathrm{UCH}$, even more significant is the content of the planning implemented within the limits of such zones. In other words, what is more important is to properly allocate and manage the sea uses and activities, so that synergies are promoted and conflicts are avoided. This section identifies activities that are compatible with $\mathrm{UCH}$, as well as activities affecting and seriously threatening this type of resource.

According to the existing literature and research experience, maritime activities that constitute threats to and may directly affect and damage UCH, include [22,28-31]: (a) All construction reaching the seabed (mining of fossils and metals, drilling, aggregates extraction, etc.); (b) all installations making use of the seabed (pipelines, cables, etc.); (c) certain fishing techniques (e.g., dragnet bottom-trawling) that create a great disturbance to all living and non-living resources found on the seabed; and (d) military and defense exercises and activities. Another serious threat now gaining intensity is 
human interference directed at $\mathrm{UCH}$, a result of technological developments that allow easier access by humans to submerged assets [2,32].

Beyond the above maritime activities directly affecting and harming $\mathrm{UCH}$, there are also others that may indirectly affect submerged cultural assets. As the sea constitutes a blue continuum-where the flow of materials (substances, pollution, etc.) is unimpeded, following unpredictable patterns of dispersion and movement- $\mathrm{UCH}$ may also be threatened by activities that take place far from $\mathrm{UCH}$ sites [33]. Such activities include: Fossil fuel extraction, maritime transport, and military activities, i.e., all kinds of activities that threaten marine resources in case of technological disasters (e.g., oil spills). Beyond those activities, pollution from marine and land-based activities (e.g., marine litter, uncontrolled waste water disposal in the sea) is another threat for $\mathrm{UCH}[26,28,30,33-35]$.

Regarding the compatible uses and the synergies created with $\mathrm{UCH}$, these may include: (a) Nature reserves and natural heritage sites (designated or not as MPAs), with which cultural assets co-exist harmoniously and enjoy recognition and protection; (b) scientific research ensuring enhancement of knowledge and education; and (c) recreation and marine tourism activities (wildlife watching, scuba diving, etc.), so that humankind benefits from the existence of $\mathrm{UCH}[8,29,36]$. However, especially regarding tourism development and leisure opportunities, the challenges faced raise controversy. While tourism development is a promising option both in terms of job opportunities and economic growth, risks also exist, mainly due to the direct contact of humans with the submerged assets.

In short, the identification of compatible and incompatible uses with $\mathrm{UCH}$ is of prime importance when planning in areas including UCH resources. MSP implementations may ensure that conflicts and threats are avoided, creating conservation of $\mathrm{UCH}$ resources for present and future generations. Synergies may also be achieved, adding economic value to the UCH capital, which is a significant task if $\mathrm{UCH}$ is to receive priority over other activities and maritime regimes. Furthermore, the identification of conflicting and non-compatible uses is essential for coastal states, in order to establish restrictions and regulations, as well as safety distance limits between $\mathrm{UCH}$ and other uses, thus assisting decisionmaking (licensing, permissions, etc.) for activities in the buffer zones of $\mathrm{UCH}$.

\section{Implications and Prospects in Greece}

\subsection{The Context and Legislation for UCH Management and Preservation}

Greece is a country with a long and glorious past that is reflected in its rich and magnificent monumental heritage spread throughout the country and well beyond its territorial seas. Indeed, according to a study conducted in 2010 [37], Greece counts more than 10,000 archaeological sites and ancient monuments and another few thousand monuments of modern times, found both on land and in the sea.

Having full acknowledgment of the invaluable cultural property located in areas of national jurisdiction (and well beyond), the Greek state (under the responsibility of the Ministry of Culture) has long established a full and integrated legislative framework to tackle all issues related to the management and protection of its cultural assets, both on land and in the sea [38,39] (see also Table 1). The first Greek law that governed Greek antiquities was passed in 1834 . This was subject to amendments until 2002, when the latest law was adopted. This law (No 3028) covers national heritage, both tangible and intangible, of all periods of time, regardless of their location (even in areas beyond the national jurisdiction). The law also provides regulations on the preservation and management of the Greek monumental heritage, the most important being those included in Art. 13, introducing protection zoning for assets found both on land and in the sea. Two kinds of protection zoning were introduced [40]:

Protection zone $\mathbf{A}$ is the zone of absolute protection that usually delimitates the strict area of the monument or archaeological site. Within this zone, all kinds of interventions and constructions are prohibited (with the exception of actions taken for the restoration and preservation of the monument). 
Protection zone B is the buffer zone, extending to such a distance as to include areas that interact with the monument and its surrounding landscape. According to the provisions of law 3028, in zone B, planning must include land-use restrictions and regulations, ensuring that the monument is protected from any kind of visual, aural, and olfactory nuisance, as well as other nuisances that are provoked by inappropriate action and excessive construction activity.

Table 1. Cultural heritage protection zones (jurisdiction under the Ministry of Culture).

\begin{tabular}{cc}
\hline 1932 & Buffer zone of $\mathbf{5 0 0}$ m radius (zone giving jurisdiction to the Ministry of Culture over building permissions) \\
1950 & Landscapes of outstanding natural beauty (zone transferred to the Ministry for the Environment in 2011) \\
2002 & Protection zone A and protection zone B \\
\hline & Source: adapted from [40].
\end{tabular}

In short, including a clear spatial dimension (planning tools and zones) in law 3028 was certainly a breakthrough in Greek cultural heritage legislation. However, what is more important than designating monuments and then delimitating protection zones is how to be consistent with the spirit of the cultural heritage legislation and the objective of preservation, without suppressing the need of areas to grow and develop, and the necessity of generations to evolve socially and economically.

\subsection{UCH Sites and Designations}

Greece has a long and rich cultural past, and it is estimated that a great number of cultural objects and sites exist on its seabed. So far, however, very few of them have been discovered and even fewer have been revealed to the public. This is deemed to be the result of: (a) The rough oceanography of the Greek sea floor, making the discovery of cultural objects very difficult, unless they are found very close to the shore or discovered by accident; $(b)$ the natural phenomena and processes occurring underwater and on the seabed, which make it extremely difficult to locate objects and to find them well-preserved; (c) the scarcity of marine archaeological research in Greek territorial waters, mainly due to the difficulties and the high cost of working underwater, as well as the specialized experience and equipment needed; and (d) the secrecy with which most related research data and discoveries are treated, in order to avoid illicit actions (given that surveillance of underwater objects is almost impossible).

So far, the only official data in Greece (open to the public) concerning UCH sites and objects, are provided by the Hellenic Ministry of Culture and specifically, through its official data-base, also available online (http:/ / listedmonuments.culture.gr). This data-base, however, includes information only on UCH sites that come with an act of designation. This means that no information is included either on submerged objects not yet designated nor on objects with high cultural value that should remain unknown to the public.

Given the above, this paper attempted original research in the official (open to the public) data-base of the Ministry of Culture, in order to record the designated UCH sites of Greece. According to this research, in total, 88 underwater archaeological sites were recorded, spread throughout the Greek territorial waters (see Table 2). The highest number of sites was recorded in the marine space surrounding the Peloponnese region, although in total, UCH presence is higher in the Aegean Sea.

The designation of UCH sites began in Greece in 1948 (in the commercial port of Rhodes). While these sites derive mainly from the Classical Era, their origin and construction range from the Bronze Age to the Hellenistic period. Regarding their location, the majority of designated UCH archaeological sites are coastal. This means they cover both terrestrial and marine areas and usually regard ancient cities that were eventually submerged (due to earthquakes, geological processes, etc.). On the contrary, those found totally underwater are usually ancient port infrastructures, walls, and sometimes wrecks with loads. 
Table 2. Designated UCH sites in Greece.

\begin{tabular}{|c|c|c|c|}
\hline Regions & Total (Underwater *) & $\begin{array}{l}\text { First and Last Year of } \\
\text { Designation }\end{array}$ & UCH Period of Construction \\
\hline Peloponnese & $21(2)$ & 1950-2009 & Bronze Age up to post-Byzantine Era \\
\hline South Aegean & $16(7)$ & 1948-2012 & Prehistoric Era up to post-Byzantine Era \\
\hline Crete & $13(4)$ & 1967-2005 & Bronze Age up to modern Greek Era \\
\hline Thessaly & $10(5)$ & $1965-2004$ & Classical Era up to post-Byzantine Era \\
\hline Ionian Islands & $3(-)$ & 1994-2003 & Late Bronze Age up to post-Byzantine Era \\
\hline Central Macedonia & $2(2)$ & 1987-2003 & Prehistoric Era up to Byzantine Era \\
\hline Eastern Macedonia & $1(-)$ & 1987 & Classical Era \\
\hline Epirus & - & - & - \\
\hline Western Greece & - & - & - \\
\hline
\end{tabular}

* Number of sites being totally underwater (not extending both to terrestrial and marine parts). Source: http:

/ / listedmonuments.culture.gr (official data-Hellenic Ministry of Culture).

In short, UCH sites of Greece are of great historical value and of great national and international importance. However, the ones included in the database of the Ministry of Culture do not constitute the full list. Their number is estimated to be much higher, if one also considers those yet to be discovered (accidentally or not) or those yet to be designated, if the state chooses for inclusion in the list of the cultural heritage of the country. Whatever the actual number of UCH sites might be, existing trends in the marine space and the growing interest in allocating more human uses and installations in the sea are expected to raise controversy and dilemmas on the type of management to be adapted for $\mathrm{UCH}$. The role of MSP in this decision-making will be decisive, given that its role is to regulate "when" and "where" human activities take place at sea, ensuring these are as efficient and sustainable as possible (European Commission).

\subsection{The Blue Growth Trend and the Role of MSP in Greece: Challenges for UCH}

Situated in the east Mediterranean Basin, between the Ionian and the Aegean Seas, Greece is known for its extremely insular and coastal nature. Thousands of islands, islets, and outcrops compose the marine space of Greece, which is also characterized by great depths, hosting significant species (catches, etc.), as well as a great variety of other living and non-living resources [18,20].

Given this peculiar nature, Greece has an interesting and long tradition in maritime economic activities, taking full advantage of its coastal and marine morphology and resources. According to recent statistics, Greece is placed among the top countries in the EU in fishing exports (free fishing and aquaculture), and among those with the largest shipping fleet in the world [21]. At the same time, due to its extremely insular nature, in the Greek marine space, a dense naval transportation system exists, with sea lanes serving passenger and commercial transit, as well as marine tourism.

With its maritime tradition and oceanographic features, Greece has always had a sectorial approach to maritime spatial planning (with the exception of the two marine national parks of Zakynthos and Alonnissos, whose management plans were the first to use a place-based planning approach) [41,42]. All sectors of the Greek maritime economy are regulated by equal (in number) national policy documents (approved by the relevant ministries), with the exception of the aquaculture sector, which is the only one that has a national spatial framework (adopted in 2011, via Official Gazette No 2505/B/2011) that sets the rules and regulations for the spatial organization of aquaculture activities. The key objective of all the above sectorial policy documents and spatial plans, is always the expansion of the sector in question, both geographically and economically.

Lately, however, this sectorial approach that has prevailed in Greece (placing an emphasis on the development of specific economic sectors in the sea) is being severely challenged by a more place-based approach, especially regarding spatial planning [41]. In fact, this transition from sectorial maritime spatial planning (MSP) towards MSP under a place-based approach became official in Greece after 
the passage of the new law of 2018 (Law No 4546). According to this law (harmonizing the EU MSP Directive 2014/89), Greece must soon (i.e., before March 2021) approve maritime spatial plans under the ecosystem approach (which has as its prerequisite the endorsement of a place-based planning approach).

This latest trend in Greece towards a place-based approach in MSP is of great importance to $\mathrm{UCH}$, which is found in abundance. This is firstly because place-based MSP may effectively tackle key challenges related to the blue growth trend currently taking place in the country (mainly related to the marine tourism sector and the developments in the fossil fuel extraction sector). Secondly, MSP under a place-based approach may ensure better organization and regulation of maritime activities that may directly or indirectly affect UCH. Finally, it can also provide solutions to upgrade the economic value of UCH to make it more appealing compared to other economic activities (having a more direct and extractive economic value).

\section{Conclusions and Discussion}

Underwater cultural heritage constitutes an invaluable resource, from an ecological, educational, and economic point of view, that needs acknowledgement and proper treatment to continue offering great benefits to humankind. However, despite its indisputable value, $\mathrm{UCH}$ has mainly been neglected in most marine planning attempts, given the sectorial approach that has prevailed until now when planning in the sea, placing an emphasis on certain economic activities and regimes. Lately, however, now that maritime spatial planning (MSP) under a place-based approach has been gaining ground all over the world, the opportunities and challenges for $\mathrm{UCH}$ are considerably different.

In Greece, although UCH resources are estimated to exist in abundance, so far, very few UCH sites have been discovered and even fewer have been shared with the public. The existing blue growth trend and the growing interest in allocating more human uses and installations in the sea are expected to raise controversy and dilemmas regarding the type of management to be adapted for UCH. Therefore, Greece has to proceed at a faster pace towards the elaboration of maritime spatial plans under a place-based approach, so that human activities are wisely regulated, avoiding user-use and user-environment conflicts and creating conditions for $\mathrm{UCH}$ conservation for present and future generations.

The key argument of this paper is that MSP can become a key procedure and a valuable ally of UCH. However, it is important to keep in mind that maintaining and integrating UCH into MSP requires that such resources are highly prioritized compared to other resources and maritime regimes. This challenge is probably the greatest for $\mathrm{UCH}$ in the era of blue growth, especially if one considers that even if $\mathrm{UCH}$ constitutes a resource of great socio-cultural value, it has very few direct or extractive uses of economic importance. Therefore, a future task for spatial planners and decision-makers will be how to reconcile the blue growth trend with $\mathrm{UCH}$ preservation and how to upgrade the economic value of UCH to make the conservation and enhancement of such resources a priority in MSP.

Given the above, the key issues discussed in this paper can have a practical application in the forthcoming development of maritime spatial plans in Greece, under a place-based approach. However, if the $\mathrm{UCH}$ parameter is to be properly considered in this process, future research must focus on a selected marine pilot area in Greece, where apart from the designated UCH sites, other submerged objects and coastal assets (having a cultural value) will also be evaluated (such as modern shipwrecks, submerged buildings, lighthouses, etc.). In this research, a key objective will be to identify and apply suitable methods (e.g., environmental economics) to value and evaluate $\mathrm{UCH}$ in a specific marine area. This will inevitably contribute to the preparation of Greece's first place-based maritime spatial plans, which must be completed and approved before 2021.

Funding: This research received no external funding.

Conflicts of Interest: The authors declare no conflict of interest. 


\section{References}

1. Bailey, G.N.; Flemming, N. Archaeology of the continental shelf: Marine resources, submerged landscapes and underwater archaeology. Quat. Sci. Rev. 2018, 27, 2153-2165. [CrossRef]

2. Dromgoole, S. Underwater Cultural Heritage and International Law; University Press: Cambridge, UK, 2013; Volume 101.

3. Brodie, N.; Tubb, K.W. Illicit Antiquities: The Theft of Culture and the Extinction of Archaeology; Routledge: London, UK, 2003.

4. Carducci, G. New Developments in the Law of the Sea: The UNESCO Convention on the Protection of Underwater Cultural Heritage. Am. J. Int. Law 2002, 96, 419-434. [CrossRef]

5. Dromgoole, S. UNESCO convention on the protection of the underwater cultural heritage. Int. J. Mar. Coast. Law 2001, 18, 59-108.

6. Migliorino, L. In situ protection of the underwater cultural heritage under international treaties and national legislation. Int. J. Mar. Coast. Law 1995, 10, 483. [CrossRef]

7. Strati, A. Deep seabed cultural property and the common heritage of mankind. Int. Comp. Law Quart. 1991, 40, 859-894. [CrossRef]

8. Smith, H.; Couper, A. The management of the underwater cultural heritage. J. Cult. Herit. 2003, 4, $25-33$. [CrossRef]

9. Whitehead, J.C.; Finney, S.S. Willingness to pay for submerged maritime cultural resources. J. Cult. Econ. 2003, 27, 231-240. [CrossRef]

10. Claesson, S. An ecosystem-based framework for governance and management of maritime cultural heritage in the USA. Mar. Pol. 2009, 3, 698-706. [CrossRef]

11. Daire, M.Y.; Lopez-Romero, E.; Proust, J.N.; Regnauld, H.; Pian, S.; Shi, B. Coastal changes and cultural heritage (1): Assessment of the vulnerability of the coastal heritage in Western France. J. Isl Coast. Arch. 2012, 7, 168-182. [CrossRef]

12. McVey, J.; Erlandson, J. As the world warms: Rising seas, coastal archaeology, and the erosion of maritime history. Coast. Conserv. 2012, 16, 137-142.

13. Durán, R.; Farizo, B.A.; Vázquez, M.X. Conservation of maritime cultural heritage: A discrete choice experiment in a European Atlantic Region. Mar. Pol. 2015, 51, 356-365. [CrossRef]

14. Graham, B. Heritage as knowledge: Capital or culture? Urban Stud. 2002, 39, 1003-1017. [CrossRef]

15. Orams, M. Marine Tourism: Development, Impacts and Management; Routledge: London, UK; New York, NY, USA, 1999.

16. Hall, M. Trends in ocean and coastal tourism: The end of the last frontier? Ocean Coast. Manag. 2001, 44, 601-618. [CrossRef]

17. Smith, H.; Maes, F.; Stojanovic, T.; Ballinger, R. The integration of land and marine spatial planning. J. Coast. Conserv. Plan. 2011, 15, 291-303. [CrossRef]

18. Millennium Ecosystem Assessment (MEA). Ecosystem and Humans' Well-Being: Synthesis; Island Press: Washington, DC, USA, 2005.

19. Papageorgiou, M. Underwater cultural heritage facing spatial planning: Legislative and technical issues. J. Ocean Coast. Manag. 2018, 165, 195-202. [CrossRef]

20. Douvere, F. The importance of Marine Spatial Planning in advancing ecosystem-based sea use management. Mar. Pol. 2008, 32, 762-771. [CrossRef]

21. Gilliland, P.; Laffoley, D. Key elements and steps in the process of developing ecosystem-based marine spatial planning. Mar. Pol. 2008, 32, 787-796. [CrossRef]

22. Ehler, C.; Douvere, F. Marine Spatial Planning: A Step by Step Approach toward Ecosystem-Based Management; Intergovernmental Oceanographic Commission and Man and the Biosphere Programme; IOC Manual and Guides No 53, ICAm Dossier No 6; UNESCO: Paris, France, 2009.

23. ICES Advisory Committee on Ecosystems: Report of the Regional Ecosystem Study Group for the North Sea. Nantes, France, 2003. Available online: http://www.ices.dk/sites/pub/Publication\%20Reports/Expert\% 20Group\%20Report/rmc/2003/regns/regns03.pdf (accessed on 30 September 2018).

24. Papageorgiou, M.; Kyvelou, S. Aspects of marine spatial planning and governance: Adapting to the transboundary nature and the special conditions of the sea. Eur. J. Environ. Sci. 2018, 8, 31-37. [CrossRef] 
25. Maes, F. The international legal framework for marine spatial planning. Mar Policy. 2008, 3, 797-810. [CrossRef]

26. Edgar, G.J.; Russ, G.R.; Babcock, R.C. Marine protected areas. In Marine Ecology; Connell, S.D., Gillanders, B.M., Eds.; Oxford University Press: Oxford, UK, 2007; pp. 534-565.

27. Barr, B. Understanding and managing marine protected areas through integrated ecosystem based management within maritime cultural landscapes: Moving from theory to practice. Ocean Coast. Manag. 2013, 84, 184-192. [CrossRef]

28. Hutchinson, G. Threats to underwater cultural heritage. The problems of unprotected archaeological and historic sites, wrecks and objects found at sea. Mar. Pol. 1996, 20, 287-290. [CrossRef]

29. Flatman, J. Conserving Marine Cultural Heritage: Threats, Risks and Future Priorities. Conserv. Manag. Archaeol. Sites 2009, 11, 5-8. [CrossRef]

30. Van Haelst, S.; Pieters, M.; Demerre, I. Aggregate extraction versus archaeological heritage: How to reach a win-win? In Which Future for the Sand Extraction in the Belgian Part of the North Sea? Study Day; De Mol, L., Vandenreyken, H., Eds.; 2014; Available online: https:/ / www.researchgate.net/profile/Maarten_De_Jong5/publication/267211484_Deep_large-scale_ sand_extraction_and_ecological_landscaping_short-term_impact_results_from_the_Rotterdam_harbour_ Maasvlakte_2_borrow_pit/links/5447e1ca0cf2d62c305252cc.pdf (accessed on 30 September 2018).

31. Reeder-Myers, L.A. Cultural heritage at risk in the twenty-first century: A vulnerability assessment of coastal archaeological sites in the United States. J. Isl. Coast. Archaeol. 2015, 10, 436-445. [CrossRef]

32. Claesson, S. The value and valuation of maritime cultural heritage. Int. J. Cult. Prop. 2011, 18, 61-80. [CrossRef]

33. Khakzad, S.; Pieters, M.; Van Balen, K. Coastal cultural heritage: A resource to be included in integrated coastal zone management. Ocean Coast. Manag. 2015, 118, 110-128. [CrossRef]

34. Dromgoole, S. Revisiting the relationship between marine scientific research and the underwater cultural heritage. Int. J. Mar. Coast. Law. 2010, 25, 33-61. [CrossRef]

35. Daugstad, K.; Rønningen, K.; Skar, B. Agriculture as an upholder of cultural heritage? Conceptualizations and value judgements-A Norwegian perspective in international context. J. Rural Stud. 2006, 22, 67-81. [CrossRef]

36. Flores-de la Hoya, A.; Godínez-Domínguez, E.; González-Sansón, G. Rapid assessment of coastal underwater spots for their use as recreational scuba diving sites. Ocean Coast. Manag. 2018, 152, 1-13. [CrossRef]

37. Beriatos, E.; Papageorgiou, M.; Lainas, I.; Nikolakopoulou, C. Towards a sustainable management of cultural heritage in Greek cities and Regions: The role of spatial planning. In Proceedings of the 47th ISOCARP Congress Liveable cities-Urbanizing World: Meeting the Challenge. Available online: http: / / www.isocarp.net/Data/case_studies/2055.pdf (accessed on 30 September 2018).

38. Christofilopoulos, C. Cultural Environment_Spatial Planning and Sustainable Development: Shaping Cultural (Man-Made) Environment through Spatial and Urban Planning: The City of the 21st Century; P.N. Sakkoulas: Athens, Greece, 2002. (In Greek)

39. Trova, E. The Cultural Environment in the Constitution; Sakkoulas: Athens, Greece, 2003. (In Greek)

40. Papageorgiou, M. Planning practices for the protection of cultural heritage in Greece: Lessons learnt from the Greek UNESCO sites. Eur. Spat. Res. Pol. 2015, 22, 111-125. [CrossRef]

41. Papageorgiou, M. Marine Spatial Planning and the Greek experience. Mar. Pol. 2016, 74, 18-24. [CrossRef]

42. Papageorgiou, M. Spatial planning in transition in Greece: A critical overview. Eur. Plan. Stud. 2017, 25, 1818-1833. [CrossRef]

(C) 2019 by the author. Licensee MDPI, Basel, Switzerland. This article is an open access article distributed under the terms and conditions of the Creative Commons Attribution (CC BY) license (http:// creativecommons.org/licenses/by/4.0/). 